\title{
Pengaruh Wadah dan Lama Penyimpanan terhadap Kualitas Fisik dan Jumlah Bakteri Susu Sapi Friesian Holstein di Benlutu
}

Novita Teme ${ }^{\mathrm{a}}$, Stefanus $\mathrm{Sio}^{\mathrm{b}}$, Theresia Ika Purwantiningsih ${ }^{\mathrm{c}}$

${ }^{a}$ Fakultas Pertanian, Universitas Timor, Kefamenanu, TTU - NTT, Indonesia, email: novieteme@ gmail.com

${ }^{b}$ Fakultas Pertanian, Universitas Timor, Kefamenanu, TTU - NTT, Indonesia, email: stefsio67@ gmail.com

${ }^{c}$ Fakultas Pertanian, Universitas Timor, Kefamenanu, TTU - NTT, Indonesia, email: theresiaicha@ gmail.com

\section{Article Info}

\section{Article history:}

Received 17 Juni 2019

Received in revised form 29 Juni 2020

Accepted 12 Januari 202

https://doi.org/10.32938/ja.v5i1.753

Keywords:

Jenis wadah susu

Kualitas fisik susu

Lama penyimpanan susu

Total bakteri susu

\section{Abstrak}

Penelitian ini telah dilaksanakan di Laboratorium Kimia Universitas Widya Mandira Kupang pada tanggal 4 Desember sampai denga tanggal 22 Desember 2018. Penelitian ini bertujuan untuk mengetahui kualitas fisik susu Sapi Friesian Holstein, jumlah total bakteri dalam jenis wadah dan lama penyimpanan yang berbeda, serta dapat memberikan informasi kepada masyarakat mengenai jenis wadah dan lama penyimpanan susu segar yang baik sehingga mutu dan kualitas susu tetap terjaga. Penelitian ini menggunakan susu sega dengan wadah penyimpanan yang berbeda, yakni wadah berbahan kaca, plastik, dan plastik komersial. Rancangan percobaan yang digunakan adalah rancangan acak lengkap pola faktorial dengan $4 \times 3$ perlakuan dan 4 kali ulangan. Perlakuan terdiri dari W0= wadah berbahan kaca, $\mathrm{W} 1=$ wadah berbahan plastik, dan $\mathrm{W} 2=$ wadah berbahan Tupperware yang disimpan selama 1 hari $(\mathrm{P} 0), 3$ hari $(\mathrm{P} 1), 5$ hari (P2), dan 7 hari (P3). Adapun variabel yang diamati adalah uji organoleptik, titrasi keasaman, pH, dan uji TPC. Hasil sidik ragam anova menunjukkan wadah penyimpanan dan lama penyimpanan berpengaruh sangat signifikan $(\mathrm{P}<0,05)$ terhadap derajat keasaman secara tetrimetri, $\mathrm{pH}$, dan TPC. Selanjutnya, interaksi dari wadah penyimpanan dan lama penyimpanan terhadap derajat keasaman dan TPC sangat signifikan $(\mathrm{P}<0,05)$; namun interaksi untuk $\mathrm{pH}$ tidak signifikan $(\mathrm{P}>0,05)$. Kesimpulan dari penelitian ini menjelaskan bahwa susu yang disimpan dalam wadah berbahan botol plastik dengan lama penyimpanan 1 hari memiliki kualitas yang lebih baik dibandingkan susu dalam wadah berbahan botol kaca dan Tupperware. Hal ini dapat dilihat dari hasil uji organoleptik, titrasi keasaman, $\mathrm{pH}$, dan uji TPC.

\section{Pendahuluan}

Susu segar merupakan bahan makanan yang bergizi tinggi karena mengandung zat-zat makanan yang lengkap dan seimbang seperti protein lemak, karbohidrat, mineral, dan vitamin yang sangat dibutuhkan oleh manusia. Selain mengandung zat-zat yang lengkap, susu juga sangat baik untuk pertumbuhan bakteri. Nilai gizi yang tinggi juga menjadikan susu sebaga medium yang sangat disukai oleh mikrooganisme untuk pertumbuhan dan perkembangannya sehingga dalam waktu yang sangat singkat, susu menjadi tidak layak dikonsumsi bila tidak ditangani secara tepat (Mennane et al., 2007).

Berbagai upaya dilakukan untuk mencegah pertumbuhan bakteri pada susu agar lebih tahan lama sekaligus kualitasnya tetap dipertahankan. Salah satu upaya yang telah dilakukan adalah dengan menyimpan susu dalam bentuk beku menggunakan freezer. Menurut Amanah et al. (2013), susu akan bertahan lebih lama jika disimpan dalam freezer. Namun penelitian yang dilakukan Hudaya (2002) menunjukkan bahwa proses pembekuan susu dapa menyebabkan pecahnya emulsi lemak disertai perubahan fisik dan kimia dari susu tersebut.

Bahan pengemas memegang peranan penting dalam mempertahankan kualitas pangan serta mempengaruhi perubahan yang tidak diinginkan selama proses pengemasan, transportasi, dan penyimpanan (Steinka et al., 2006) Pengemasan efektif melindungi produk dari kontaminasi mikroba, sinar, dan oksigen (Vasilla et al., 2002). Pemilihan bahan pengemas yang tepat akan mempengaruhi perubahan fisik, kimia, dan organoleptik produk yang dikemas (Steinka et al., 2006). Kemasan merupakan wadah yang berfungsi sebaga pelindung produk; telah dilengkapi dengan tulisan, label, dan keteranganketerangan sebagai sarana komunikasi dan promosi, serta sebagai sarana yang memberikan kemudahan bagi produsen dan konsumen. Kemudahan yang diperoleh produsen seperti kemudahan dalam penanganan, penyimpanan, dan pemasaran; sedangkan bagi konsumen, kemudahan dalam membawa dan menyimpan produk (Syarief dan Halid, 1991).

Susu merupakan media cair yang memiliki komposisi nutrisi sanga lengkap sehingga tidak dapat bertahan lama bila disimpan pada suhu kamar. Susu yang disimpan pada suhu kamar akan mudah rusak jika tidak mendapa perlakuan seperti pasteurisasi, pendinginan/pembekuan, dan pemanasan (Hamidah, 2012). Untuk meningkatkan mutu dari susu sapi perah supaya layak untuk dikonsumsi, maka dapat dilakukan pengujian secara mikrobiologik yang mengukur dan menentukan jumlah serta jenis bakteri dalam susu sapi. Menuru Benson (2002), jumlah bakteri dalam susu dapat digunakan sebagai indikator terhadap kualitas susu.

\section{Metode}

\subsection{Lokasi dan Waktu Penelitian}

Penelitian ini telah dilaksanakan pada bulan Desember 2018 bertempa di Peternakan Claretian Novisiat Desa Benlutu, Kecamatan Batu Putih, Kabupaten Timor Tengah Selatan (TTS) dan di Laboratorium Kimia Universitas Katolik Widya Mandira, Kupang.

\subsection{Alat dan Bahan}

Alat yang digunakan dalam penelitian ini adalah cawan petri, inkubator, colony counter, lampu spiritus, larutan buffer, medium plate count agar, gelas beaker, wadah penyimpanan susu (botol berbahan kaca, botol berbahan plastik biasa, dan botol berbahan Tupperware), serta $\mathrm{pH}$ meter. Bahan yang digunakan berupa susu sapi segar.

\subsection{Metode Penelitian}

Penelitian ini menggunakan Rancangan Acak Lengkap (RAL) Pola Faktorial dengan 4 × 3 perlakuan dan 4 kali ulangan, dimana $\mathrm{P}=$ Lama Penyimpanan dan $\mathrm{W}=$ Wadah Penyimpanan.
Lama penyimpanan susu dengan suhu $4^{\circ} \mathrm{C}$

$\mathrm{P}_{0} \quad$ Lama penyimpanan susu selama 1 hari

$\mathrm{P}_{1}$ = Lama penyimpanan susu selama 3 hari

$\mathrm{P}_{2}=$ Lama penyimpanan susu selama 5 hari

$\mathrm{P}_{3}=$ Lama penyimpanan susu selama 7 hari

Wadah penyimpanan susu:

$\mathrm{W}_{0}=$ Wadah berbahan kaca.

$\mathrm{W}_{1}=$ Wadah berbahan plastik biasa.

$\mathrm{W}_{2}=$ Wadah berbahan Tupperware

Perlakuannya terdiri dari 12 perlakuan dengan 4 kali ulangan sehingga terdapat 48 satuan percobaan yakni $\mathrm{P}_{0} \mathrm{~W}_{0}, \mathrm{P}_{0} \mathrm{~W}_{1}, \mathrm{P}_{0} \mathrm{~W}_{2}, \mathrm{P}_{1} \mathrm{~W}_{0}, \mathrm{P}_{1} \mathrm{~W}_{1}, \mathrm{P}_{1} \mathrm{~W}_{2}$ $\mathrm{P}_{2} \mathrm{~W}_{0}, \mathrm{P}_{2} \mathrm{~W}_{1}, \mathrm{P}_{2} \mathrm{~W}_{2}, \mathrm{P}_{3} \mathrm{~W}_{0}, \mathrm{P}_{3} \mathrm{~W}_{1}$, dan $\mathrm{P}_{3} \mathrm{~W}_{2}$

\subsection{Prosedur Penelitian}

Penelitian ini dilakukan dengan menggunakan susu sapi segar yang diperoleh dari komunitas Claretian tepatnya di Desa Benlutu, Kecamatan Bat Putih; berjarak $\pm 10 \mathrm{~km}$ dari ibukota Soe. Sampel susu sapi sebanyak \pm 10 liter diambil pada jam 7 pagi, kemudian dimasukkan dalam coolbox dan dibawa ke laboratorium dengan suhu $0^{\circ} \mathrm{C}-4^{\circ} \mathrm{C}$. Sampel sampai di laboratorium langsung disimpan dalam freezer dengan wadah dan lama penyimpanan yang berbeda. Sampel susu pada perlakuan 0 hari langsung dianalisa TPC (Total Plate Count) untuk menghitung jumlah koloni bakteri dalam susu segar.

\subsection{Variabel Penelitian}

\subsubsection{Uji Organoleptik}

Pemeriksaan dan penilaian terhadap uji organoleptik susu sapi yang dilakukan oleh panelis meliputi:

1) Bau: Bau susu segar mempunyai bau yang khas yang segar; tidak tercampur bau asing.

2) Warna: Uji warna susu segar dapat diamati dengan bantuan penempatan di tabung reaksi ataupun gelas beaker; warna susu adalah putih kekuningan.

3) Rasa: Uji rasa susu segar dapat dilakukan setelah susu terlebih dahulu dipanaskan. Rasa susu mempunyai rasa yang khas agak manis, gurih, segar, serta bebas dari rasa asin.

Panelis dalam pengujian organaoleptik berjumlah \pm 15 orang dengan kriteria sebagai berikut :

1) Mempunyai kepekaan yang dibutuhkan untuk penilaian terhadap warna, bau, dan rasa.

2) Tidak cacat fisik artinya tidak ada gangguan pada indra penglihatan, penciuman, dan perasa.

3) Tidak mengalami gangguan pernapasan.

4) Tidak stres, artinya pikiran tidak terganggu pada saat penilaian.

5) Tidak terburu-buru dalam melakukan penilaian baik warna, bau, maupun rasa

Skala uji organoleptik warna, aroma, dan rasa susu dapat dilihat pada Tabel 1, 2, dan 3 .

\subsubsection{Titrasi Keasaman}

Cara kerja yang dilakukan adalah alat dan bahan disiapkan kemudian susu sebanyak $50 \mathrm{ml}$ dimasukkan ke dalam erlenmeyer, lalu ditambahkan 3-4 tetes larutan indikator pp dan larutan $\mathrm{NaOH}$ sebanyak 0,25 N. Dititrasi sampai terlihat warna merah muda.

\subsubsection{Pengukuran pH}

Pengerjaan diawali $\mathrm{pH}$ meter dikalibrasi/distandarisasi dengan larutan buffer, dicuci dengan aquades, kemudian sampel diperiksa $\mathrm{pH}$-nya dengan memasukkan elektroda $\mathrm{pH}$ meter ke dalam larutan susu yang akan diperiksa. 
Pengamatan dilakukan hingga angka yang diperoleh menunjukan kondisi yang konstan.

Tabel 1. Skala uji organoleptikwarna susu segar.

\begin{tabular}{lc}
\hline Kriteria penilaian warna susu segar. & Skala \\
\hline Kuning & $0,01-1,50$ \\
Putih Kekuningan & $1,60-2,50$ \\
Putih & $2,60-3,50$ \\
Putih Pucat & $3,60-4,00$ \\
\hline
\end{tabular}

Tabel 2. Skala uji organoleptik aroma susu segar.

\begin{tabular}{lc}
\hline Kriteria penilaian aroma susu segar. & Skala \\
\hline Tidak Berbau & $0,01-1,50$ \\
Bau Susu & $1,60-2,50$ \\
Bau Busuk & $2,60-3,50$ \\
Sangat Busuk & $3,60-4,00$ \\
\hline
\end{tabular}

Tabel 3. Skala uji organoleptik rasa susu segar.

\begin{tabular}{lc}
\hline Kriteria penilaian rasa susu segar. & Skala \\
\hline Tidak Suka & $0,01-1,50$ \\
Kurang Suka & $1,60-2,50$ \\
Suka & $2,60-3,50$ \\
Sangat Suka & $3,60-4,00$ \\
\hline
\end{tabular}

\subsubsection{Uji Total Plate Count(TPC)}

Total Plate Count (TPC) merupakan salah satu metode yang dilakukan untuk menghitung jumlah koloni bakteri dalam susu segar. Tahapan dalam analisa SPC meliputi:

1) $0,1 \mathrm{ml}$ susu segar dicampur ke medium NA (Nutrient Agar) sebanyak $15 \mathrm{ml}$.

2) Sampel kemudian didinginkan dan diinkubasi pada suhu $35^{\circ} \mathrm{C}$ selama \pm 48 jam.

3) Jumlah koloni diamati dan dihitung.

\subsection{Analisis Data}

Data yang diperoleh dianalisis menggunakan analisis deskriptif (organoleptik) dan analisis sidik ragam (Anova) dari Rancangan Acak Lengkap (RAL) Pola Faktorial, kemudian dilanjutkan dengan uji Duncan. Teknis analisis statistik dalam penelitian percobaan menggunakan prosedur Steel and Torrie (1995). Model matematisnya adalah:

$$
\text { Yijk }=\mu+\alpha i+\beta j+(\alpha \beta) i j+\varepsilon i j k .
$$

\section{Keterangan:}

Yijk = Respon pengamatan pada perlakuan ke-i, ulangan ke-k.

$\mu \quad=$ Nilai tengah umum respon percobaan.

ai $\quad=$ Pengaruh perlakuan I ke-i ulangan ke-k

$\beta \mathrm{j} \quad=$ Pengaruh perlakuan II ke-j ulangan ke-k

$(\alpha \beta) \mathrm{ij}=$ Pengaruh interaksi perlakuan ke-i dan perlakuan ke-j.

cijk = Pengaruh galat perlakuan I ke-i dengan perlakuan II ke-j ulangan ke-k.

\section{Hasil dan Pembahasan}

\subsection{Uji Organoleptik}

Uji organoleptik dilakukan oleh 15 panelis. Panelis bertindak sebagai instrumen analisis sensori dan menentukan responnya terhadap sifat bahan yang diuji. Kriteria penilaian uji organoleptik meliputi warna, aroma, dan rasa yang disandingkan dengan uji kesukaan sebagai respon dari skala sensori yang dipilih.

\subsubsection{Warna}

Warna merupakan atribut sensori pertama yang dapat dilihat langsung oleh panelis. Suatu bahan yang dinilai bergizi, enak, dan teksturnya sangat baik tidak akan dimakan apabila memiliki warna yang tidak sedap dipandang atau memberikan kesan telah menyimpang dari warna yang seharusnya (Setyaningsih et al., 2010). Skala indikator penilaian uji organoleptik warna susu segar dengan jenis wadah dan lama penyimpanan yang berbeda dapat dilihat pada Tabel 4.

Tabel 4. Skala indikator penilaian uji organoleptik warna susu segar.

\begin{tabular}{lccccc}
\hline \multirow{2}{*}{ Jenis Wadah } & \multicolumn{4}{c}{ Lama Penyimpanan (Hari) } & \multirow{2}{*}{ Rerata } \\
\cline { 2 - 5 } & 1 & 3 & 5 & 7 & \\
\hline Botol Kaca & 2,9 & 2,8 & 2,9 & 3,2 & 3,0 \\
Botol Plastik & 2,7 & 2,6 & 2,9 & 3,2 & 2,8 \\
Tupperware & 2,7 & 2,7 & 2,7 & 2,7 & 2,7 \\
Rerata & 2,8 & 2,7 & 2,8 & 3,0 & \\
\hline
\end{tabular}

Keterangan: Skor Penilaian: 0,01-1,5=Kuning, 1,6-2,5=PutihKekuningan, 2,6-3,5=Putih, 3,6-4,00=Putih Pucat.

Hasil uji organoleptik warna susu segar pada Tabel 4 menunjukkan perlakuan dengan jenis wadah botol kaca, botol plastik, dan Tupperware dengan penyimpanan 1-7 hari rata-rata memiliki nilai kisaran 2,7 hingga 3,0 yang artinya susu tersebut berwarna putih. Hal ini sesuai dengan kebijakan Standardisasi Nasional Indonesia 01-3141-1998 yang menunjukkan bahwa tidak ada perubahan warna pada susu segar. Hal ini menggambarkan bahwa wadah penyimpanan tidak berpengaruh terhadap warna susu segar.

\subsubsection{Aroma dan Rasa}

Aroma adalah bau yang ditimbulkan oleh rangsangan kimia yang tercium oleh syaraf-syaraf olfaktori yang berada dalam rongga hidung (Soekarto, 1990). Skala indikator penilaian uji organoleptik aroma susu segar dengan jenis wadah dan lama penyimpanan yang berbeda dapat dilihat pada Tabel 5 .

Tabel 5. Skala indikator penilaian uji organoleptik aroma susu segar.

\begin{tabular}{lccccc}
\hline \multirow{2}{*}{ Jenis wadah } & \multicolumn{4}{c}{ Lama Penyimpanan (Hari) } & \multirow{2}{*}{ Rerata } \\
\cline { 2 - 4 } & 1 & 3 & 5 & 7 & \\
\hline Botol Kaca & 1,8 & 1,8 & 2,7 & 3,7 & 2,5 \\
Botol Plastik & 1,7 & 1,6 & 3,1 & 3,6 & 2,5 \\
Tupperware & 1,7 & 1,6 & 2,9 & 3,7 & 2,5 \\
Rerata & 1,7 & 1,6 & 2,9 & 3,6 & \\
\hline Kenannnnnnn
\end{tabular}

Keterangan: Skor Penilaian: 0,01-1,5= TidakBerbau; 1,6-2,5= Bau Susu; 2,6-3,5= Bau

Busuk; 3,6-4,00= Sangat Busuk

Hasil uji organoleptik aroma menunjukkan bahwa jenis wadah botol kaca, botol plastik, dan Tupperware dengan lama penyimpanan 1 dan 3 hari tidak mengalami perubahan aroma; yang artinya susu masih dalam keadaan baik dan sesuai dengan Syarat Mutu Susu Segar Berdasarkan SNI 01-31411998. Tapi pada hari ke-5 sampai hari ke-7, susu mulai mengalami penurunan kualitas; dimulai dari bau busuk menjadi sangat busuk yang berarti susu mulai mengalami kerusakan. Penyebab kerusakan pada susu salah satunya akibat kontaminasi mikroba. Mikroba susu dapat berasal dari luar ambing yang masuk melalui puting pasca pemerahan atau saat proses pemerahan. Kandungan susu berupa protein, lemak, mineral, serta air yang mudah bereaksi dan terdegradasi menyebabkan susu mudah sekali mengalami kerusakan. Kandungan nutrisi susu mampu mendorong aktivitas enzim yang merupakan media terbaik untuk perkembangan mikroba terutama pada kondisi lingkungan dengan suhu dan kelembapan yang tinggi. Pencemaran mikroba susu dapat berasal dari sapi, peralatan pemerahan, ruang penyimpanan yang kurang bersih, debu, udara, lalat, dan penanganan oleh manusia. Hoffman dan Jorgensen (2008) menyatakan bahwa bau susu mudah berubah dari bau yang sedap menjadi yang tidak sedap. Bau ini dipengaruhi oleh sifat lemak susu yang mudah menyerap bau di sekitarnya.

Rasa asli susu hampir tidak dapat diterangkan; tetapi yang jelas menyenangkan dan agak manis. Rasa manis ini berasal dari laktosa sedangkan rasa asin berasal dari klorida, sitrat, dan garam-garam mineral lainnya. Buckle et al. (2009) menyatakan bahwa rasa yang kurang normal mudah sekali berkembang di dalam susu dan hal ini mungkin merupakan akibat dari sebab fisiologis, seperti rasa makanan sapi misalnya alfalfa, bawang merah, bawang putih, dan cita rasa alga yang akan masuk ke dalam susu jika bahan tersebu mencemari makanan dan air minum sapi. Skala indikator penilaian uji organoleptik rasa susu segar dengan jenis wadah dan lama penyimpanan yang berbeda dapat dilihat pada Tabel 6 .

Tabel 6. Skala indikator penilaian uji organoleptik rasa susu segar.

\begin{tabular}{lccccc}
\hline \multirow{2}{*}{ Jenis wadah } & \multicolumn{4}{c}{ Lama Penyimpanan (Hari) } & \multirow{2}{*}{ Rerata } \\
\cline { 2 - 5 } & 1 & 3 & 5 & 7 & \\
\hline Botol Kaca & 3,1 & 3,1 & 2,0 & 1,7 & 2,5 \\
Botol Plastik & 3,2 & 3,1 & 1,8 & 1,7 & 2,5 \\
Tupperware & 3,0 & 2,6 & 2,0 & 2,0 & 2,15 \\
Rerata & 3.1 & 2,9 & 1,9 & 1,8 & \\
\hline Kennnnnnn
\end{tabular}

Keterangan: Skor Penilaian: 0,01-1,5= TidakSuka; 1,6-2,5= Kurang Suka; 2,6-3,5= Suka; 3,6-4,00= Sangat Suka

Hasil penelitian menunjukkan bahwa pada perlakuan dengan jenis wadah botol kaca, botol plastik, dan Tupperware; rasa sangat baik hingga hari ke 3 , sedangkan pada hari ke 5 dan 7; susu mulai mengalami kerusakan dimana rasa susu mulai berubah. Perubahan ini ditandai dengan tingkat kesukaan panelis yang mulai menurun dari suka menjadi kurang suka. Hal ini berarti lama penyimpanan berpengaruh terhadap rasa susu sedangkan wadah penyimpanan tidak berpengaruh terhadap rasa susu.

Secara organoleptik, susu akan mengalami perubahan jika terdapat perbedaan warna, rasa, dan aroma dari susu yang normal. Umumnya perubahan ini disebabkan oleh adanya aktifitas mikroorganisme dengan penyimpangan aroma yang normal. Rasa dan aroma susu segar masih normal dan mempunyai rasa sedikit manis sampai penyimpanan selama 21 jam. Perubahan rasa dan aroma terjadi pada penyimpanan lebih dari 21 jam. Hal ini disebabkan oleh bertambahnya jumlah kuman susu dan bertambahnya masa simpan (Abubakar et al., 2001).

\subsection{Titrasi Keasaman}

Susu akan semakin asam jika lama disimpan karena laktosa di dalam susu dirubah menjadi asam laktat oleh mikroorganisme. Untuk mengetahui nilai keasaman susu maka dapat diuji menggunakan derajat keasaman. Prinsip pada uji derajat asam yaitu secara titrasi menentukkan kadar asam yang terbentuk dalam susu. Asam yang terbentuk sebagian besar karena perombakan laktosa 
menjadi asam akibat kerja mikroorganisme (Dwitania dan Ida, 2013). Rata-rata titrasi keasaman yang dihasilkan dari susu segar dengan jenis wadah dan lama penyimpanan berbeda dapat dilihat pada Tabel 7.

Tabel 7. Rataan derajat keasaman susu segar yang disimpan dalam freezer $(0-$ $4^{\circ} \mathrm{C}$ ) dengan jenis wadah dan lama penyimpanan berbeda.

\begin{tabular}{lccccc}
\hline \multirow{2}{*}{ Jenis Wadah } & \multicolumn{4}{c}{ Lama Penyimpanan (Hari) } & \multirow{2}{*}{ Rerata } \\
\cline { 2 - 5 } & 1 & 3 & 5 & 7 & \\
\hline Botol Kaca & 1,92 & 2,12 & 2,23 & 2,27 & 2,14 \\
Botol Plastik & 1,87 & 1,96 & 2,07 & 2,03 & 2,03 \\
Tupperware & 1,91 & 1,97 & 2,16 & 2,23 & 2,07 \\
Rerata & 1,90 & 2,02 & 2,15 & 2,24 & \\
\hline
\end{tabular}

Hasil penelitian rata-rata derajat keasaman susu sapi yang disimpan dalam freezer pada suhu $4^{\circ} \mathrm{C}$; tertinggi terdapat pada wadah berbahan botol kaca dengan nilai 2,14 dan yang terendah terdapat pada wadah botol plastik yaitu 2,03. Untuk lama penyimpanan 1 hari, 3 hari, 5 hari, dan 7 hari tidak memberikan pengaruh yang nyata terhadap derajat keasaman. Semakin lama penyimpanan susu sapi pada freezer, rata-rata angka derajat asam semakin meningkat yang menunjukkan juga tingginya keasaman susu.

Hasil analisis statistik pola faktorial menunjukkan bahwa wadah penyimpanan dan lama penyimpanan berpengaruh sangat signifikan $(P<0,05)$ terhadap derajat keasaman secara tetrimetri. Interaksi antara kedua faktor juga menunjukkan hasil yang signifikan. Hasil uji lanjut menggunakan uji Duncan menunjukkan bahwa penyimpanan dengan menggunakan botol plastik lebih baik daripada botol kaca dan Tupperware, sedangkan penyimpanan selama 1 hari lebih baik daripada penyimpanan pada hari ke 3, 5, dan 7 .

Semakin tinggi derajat keasaman menunjukkan susu berkualitas buruk karena derajat keasaman berhubungan dengan banyaknya asam yang terbentuk di dalam susu akibat pertumbuhan mikroba. Penyebab kerusakan kualitas susu diakibatkan antara lain lewatnya batas waktu penyimpanan susu, suhu penyimpanan yang tidak stabil atau tidak sesuai standar, susu mengalami beberapa kali proses pencairan kemudian pembekuan kembali, kebersihan kandang yang tidak terjaga, pemberian pakan yang kurang berkualitas, serta tercampurnya susu dengan kolostrum pada masa kelahiran (Anonimus, 2013). Menurut Buckle et al. (1987), pertumbuhan mikroorganisme pada suatu media nutrien segar tidak langsung terjadi melainkan melewati beberapa fase pertumbuhan yang semakin lama akan meningkat dalam jangka waktu yang lama; tergantung pada suplai zat gizi, suhu, waktu, air, $\mathrm{pH}$, dan tersediannya oksigen $\left(\mathrm{O}_{2}\right)$.

\subsection{Pengukuran pH}

Nilai $\mathrm{pH}$ merupakan logaritma negatif dari aktifitas ion hidrogen dan merupakan faktor penting terhadap pertumbuhan mikroorganisme dalam produk pangan. Energi metabolisme mikrobial sangat ditentukan oleh perpindahan air pada membran, aktifitas enzim mikrobial, dan stabilitas makro molekul seluler (Zeuthen dan Bogh-Sorensen, 2003). Rata-rata nilai total bakteri yang dihasilkan dari susu segar dengan jenis wadah dan lama penyimpanan yang berbeda dapat dilihat pada Tabel 8 .

Tabel 8. Rataan nilai $\mathrm{pH}$ susu segar yang disimpan dalam freezer $\left(0-4^{\circ} \mathrm{C}\right)$ dengan jenis wadah dan lama penyimpanan yang berbeda.

\begin{tabular}{lccccc}
\hline \multirow{2}{*}{ Jenis Wadah } & \multicolumn{4}{c}{ Lama Penyimpanan (Hari) } & \multirow{2}{*}{ Rerata } \\
\cline { 2 - 5 } & 1 & 3 & 5 & 7 & \\
\hline Botol Kaca & 6,45 & 6,25 & 6,10 & 6,36 & 6,29 \\
Botol Plastik & 6,70 & 6,47 & 6,38 & 6,62 & 6,54 \\
Tupperware & 6,51 & 6,31 & 6,27 & 6,40 & 6,37 \\
Rerata & 6,55 & 6,34 & 6,25 & 6,46 & \\
\hline
\end{tabular}

\subsection{Total Plate Count (TPC)}

Total Plate Count (TPC) merupakan salah satu metode yang dilakukan untuk menghitung jumlah koloni bakteri dalam susu segar. Cara menghitung jumlah kandungan bakteri pada susu dilakukan dengan menanam sampel bakteri di dalam media Nutrien Agar (NA) untuk selanjutnya diinkubasi sehingga koloni bakteri yang tumbuh dapat dihitung. Penghitungan didasarkan pada asumsi bahwa setiap sel mikroba yang hidup dalam sampel akan tumbuh menjadi satu koloni setelah diinkubasikan dalam media biakan dan lingkungan yang sesuai. Jumlah koloni yang tumbuh merupakan perkiraan atau dugaan dari jumlah minimum mikroba dalam sampel karena koloni yang tumbuh pada lempengan agar merupakan gambaran mikroba yang dapat tumbuh dan berbiak dalam media dan suhu tertentu (Lay, 1994). Rata-rata nilai total bakteri yang dihasilkan dari susu segar dengan jenis wadah dan lama penyimpanan yang berbeda dapat dilihat pada Tabel 9 .

Tabel 9 menunjukkan bahwa rata-rata jumlah bakteri tertinggi terdapat pada jenis wadah berbahan kaca dan Tupperware dengan nilai masing-masing sebesar 160,609 dan 113,516; sementara jumlah bakteri terendah terdapat pada jenis wadah berbahan plastik yaitu 72,563. Hasil analisis statistik menunjukkan bahwa wadah penyimpanan dan lama penyimpanan berpengaruh sangat signifikan $(\mathrm{P}<0,05)$ terhadap total bakteri. Interaksi kedua faktor tersebut pun sangat signifikan, ditunjukkan dari hasil uji jarak berganda dimana wadah penyimpanan susu segar berbahan plastik dengan lama penyimpanan 1 hari lebih baik dibandingkan wadah berbahan botol kaca. Rata-rata lama penyimpanan yang memiliki nilai paling rendah terdapat pada penyimpanan selama 1 hari yaitu 68,458 dan yang paling tertinggi terdapat pada hari ke 3 serta 5; masing-masing sebesar 134,04 dan 158,417. Hal ini mungkin disebabkan karena kurangnya tingkat sterilisasi wadah, wadah yang digunakan berasal dari wadah bekas, dan rendahnya kondisi hygiene sehingga pertumbuhan mikroorganisme menjadi cepat. Cempirkova (2006) menyebutkan bahwa 64\% mikroorganisme dalam susu berasal dari hygiene yang buruk, 28\% oleh temperatur yang rendah (bakteri psikotrofik) dan penyimpanan yang tidak baik, serta $8 \%$ oleh mastitis. Hal ini diperkuat oleh Lues et al. (2010) yang berpendapat bahwa kontaminasi susu oleh bakteri selain dari penyimpanan yang buruk juga dikarenakan keadaan ambing sapi; contohnya karena infeksi.

Tabel 9. Rataan nilai total bakteri susu segar yang disimpan dalam freezer (0$4^{\circ} \mathrm{C}$ ) dengan jenis wadah dan lama penyimpanan yang berbeda.

\begin{tabular}{lccccc}
\hline \multirow{2}{*}{ Jenis Wadah } & \multicolumn{4}{c}{ Lama Penyimpanan (Hari) } & \multirow{2}{*}{ Rerata } \\
\cline { 2 - 5 } & 1 & 3 & 5 & 7 & \\
\hline Botol Kaca & 65,37 & 204,62 & 202.18 & 170,25 & 160,60 \\
Botol Plastik & 68,62 & 69,81 & 110,75 & 41,06 & 72,56 \\
Tupperware & 71,37 & 127,68 & 162,31 & 92,68 & 113,51 \\
Rerata & 68,45 & 134,04 & 158,41 & 101,33 & \\
\hline
\end{tabular}

\section{Simpulan}

Berdasarkan hasil analisis dan pembahasan, dapat disimpulkan bahwa jenis wadah berbahan botol plastik dengan lama penyimpanan 1 hari lebih baik sebagai tempat penyimpanan susu dibandingkan wadah berbahan botol kaca dan Tupperware. Hal ini dapat dilihat dari hasil uji organoleptik, titrasi keasaman, $\mathrm{pH}$, dan uji TPC.

\section{Pustaka}

Abubakar, Triyantini, R. Sunarlim, H. Setiyanto, dan Nurjannah. 2001. Effect of Temperature and Time of Pasteurization on the Milk Quality During Storage. Jurnal Ilmu Ternak dan Veterineir, 6(1); 45-50

Amanah, S., H. D. Arifin., R. E. Mudawaroch. 2013. Pengaruh Lama Penyimpanan Dalam Suhu Beku Terhadap Kadar Protein, Kadar Lemak, dan Kadar Asam Laktat Susu Kambing Peranakan Ettawa (PE). Surya agritama, 2 (2) : 51-58.

Anonimus. 2013. Menyimpan Susu Supaya Tahan Lama. Diakses pada tanggal 16 Maret 2019.

Benson, Harold J. 2002. Micrpbiological Apllications Laboratory Manual in General Microbiology . New York: McGraw-Hiil.

Buckle KA, RA Edwarda, G.H. F T, M. Woolton. 2009. Ilmu Pangan. Jakarta Universitas Indonesia.

Buckle, K. A., Edward, G. H., Fleed, W and Wotton, M. 1987. Food Science. Vicc. Cauncelor Comitte, Australia

Cempirkova, R. 2006. Factors Negatively influencing microbial contamination of milk. J. Agric. Trop. Et Subtrop. 39: 220-221.

Dwitania, D. C., Ida, B. N. S. 2013. Uji Didih, Alkohol dan Derajat Asam Susu Sapi Kemasan yang Dijual di Pasar Tradisional Kota Denpasar Veterinus, 2(4): 437-444.

Hamidah, E. 2012. Tampilan Total Bakteri dan $\mathrm{pH}$ pada Susu Kambing. (Ojs.unud.ac.id/index.php/imv/article/download). [Diakses tanggal 13 November 2018].

Hoffman, P dan Jorgensen, M. 2008. On-Farm Pasteurization of Milk On Calves. University of Wisconsin Dairy Update.

Hudaya. 2002. Penyimpanan Makanan pada Suhu Rendah dan Pengaruhnya pada Bahan Makanan. (http//www.gogreen.web.id). [Diakses tanggal 13 November 2018]

Lay, W.B. 1994. Analisis Mikroba di Laboratorium. Raja Grafindo Persada. Jakarta

Lues, J.F.R., De Beer, H., Jacoby, A., Jansen, K.E. and Shale, K. (2010) Microbial uality of milk, produced by small scale farmers in a Peri-urban area in South Africa. Afric. J. Microb. Res, 4: 1823-1830.

Manik, E. 2006. Olahan Susu. Jakarta: Pusat Unit Pangan dan Gizi. IPB. Bogor

Mennane, Z., Ouhssine, M.K. and Elyachioui, M. 2007. Hygienic quality of raw cow's milk feeding from domestic waste in two regions in Morocco. Int. J. Agric. Biol, 9: 6-47.

Setyaningsih D, Apriantono A, dan Puspita M. 2010.Analisis Sensori Untuk Industri Pangan Dan Agro. Bogor: IPB Press.

Soekarto, ST. 1990. Dasar-Dasar Pengawasan dan Standarisasi Mutu Pangan Bogor: PAU Pangan dan Gizi, FakultasTeknologi Pertanian, IPB

Standar Nasional Indonesia (SNI), 01-3141-1998. Susu Segar. Badan Standarisasi Nasional

Steel, R. G. D dan J. H. Torrie. 1995. Principles and procedure of statistics Mc Graw-Hill International Book Co. Tosho Printing Co. Ltd. Tokyo Japan.

Steinka, I., M. Morawska, M. Rutkowska And A. Kukulowicz. 2006. The influence of biological factor on properties of some traditional and new polymer used for fermented food packaging. J. Food Eng, 77(4): 771 775

Syarief, R. dan H. Halid. 1991. Teknologi Penyimpanan Pangan. Penerbit Arcan, Jakarta 
Vasilla, E., A. Badeka, E. Kondyli, I. Savvaidis And M. Kontominas. 2002.

Chemical and microbial changes in fluid milk as affected by packaging conditions. International Dairy J, 12 (9): 715 -722

Zeuthen, P and Bogh-Sorensen, L. 2003. Food preservation. Woodhead publishing limited and CRC Press LLC. Fulda, Germany. 